\title{
Relevance of dietary protein concentration and quality as risk factors for the formation of calcium oxalate stones in cats
}

\author{
Nadine Paßlack ${ }^{1} *$, Hannes Burmeier ${ }^{1}$, Thomas Brenten ${ }^{2}$, Konrad Neumann ${ }^{3}$ and Jürgen Zentek ${ }^{1}$ \\ ${ }^{1}$ Institute of Animal Nutrition, Department of Veterinary Medicine, Freie Universität Berlin, Königin-Luise-Str. 49, 14195 Berlin, Germany \\ ${ }^{2}$ Mars GmbH, Eitzer Straße 215, 27283 Verden, Germany \\ ${ }^{3}$ Institute of Biometry and Clinical Epidemiology, Charité - Universitätsmediżin Berlin, Hindenburgdamm 30, 12203 Berlin, Germany
}

(Received 12 January 2014 - Final revision received 24 March 2014 - Accepted 2 April 2014)

Journal of Nutritional Science (2014), vol. 3, e51, page 1 of 10

doi:10.1017/jns.2014.13

\section{Abstract}

The role of dietary protein for the development of feline calcium oxalate $(\mathrm{CaOx})$ uroliths has not been conclusively clarified. The present study evaluated the effects of a varying dietary protein concentration and quality on critical indices for the formation of $\mathrm{CaOx}$ uroliths. Three diets with a high protein quality (10-11\% greaves meal/diet) and a varying crude protein (CP) concentration (35, 44 and $57 \%$ in DM) were compared. Additionally, the $57 \%$ CP diet was compared with a fourth diet that had a similar CP concentration (55\% in DM), but a lower protein quality ( $34 \%$ greaves meal/diet). The $\mathrm{Ca}$ and oxalate $(\mathrm{Ox})$ concentrations were similar in all diets. A group of eight cats received the same diet at the same time. Each feeding period was divided into a $21 \mathrm{~d}$ adaptation period and a $7 \mathrm{~d}$ sampling period to collect urine. There were increases in urinary volume, urinary Ca concentrations, renal $\mathrm{Ca}$ and $\mathrm{Ox}$ excretion and urinary relative supersaturation (RSS) with $\mathrm{CaOx}$ with increasing dietary protein concentrations. Urinary $\mathrm{pH}$ ranged between 6.34 and 6.66 among all groups, with no unidirectional effect of dietary protein. Lower renal Ca excretion was observed when feeding the diet with the lower protein quality, however, the underlying mechanism needs further evaluation. In conclusion, although the observed higher urinary volume is beneficial, the increase in urinary $\mathrm{Ca}$ concentrations, renal $\mathrm{Ca}$ and $\mathrm{Ox}$ excretion and urinary RSS $\mathrm{CaOx}$ associated with a high-protein diet may be critical for the development of $\mathrm{CaOx}$ uroliths in cats.

Key words: Cats: Dietary protein: Protein quality: Renal calcium and oxalate excretion: Urinary pH

The role of dietary protein for the development of calcium oxalate $(\mathrm{CaOx})$ uroliths in cats has not been conclusively clarified. In human subjects, an increased renal oxalate $(\mathrm{Ox})$ excretion has been found to be associated with a higher protein intake ${ }^{(1)}$; however, contrary results have been observed in cats ${ }^{(2,3)}$. Up to now, the reasons for these contradicting effects in human subjects and cats remain unclear. Zentek \& Schulz ${ }^{(2)}$ hypothesised that the observed decrease in urinary Ox concentrations when feeding the high-protein (but low-fat) diets compared with the lowprotein (but high-fat) diets to the cats could possibly not result from the protein, but from the fat concentration of the diets.
Dijcker et al. ${ }^{(3)}$ also observed the highest urinary Ox concentrations in cats when feeding a high-fat diet compared with a highprotein and high-carbohydrate diet. Thus, one explanation for the contradicting effects of dietary protein on the urinary $\mathrm{Ox}$ concentration and excretion reported in human subjects and cats could be the variation in the fat concentrations of the experimental diets. This hypothesis is supported by findings in human subjects, where a high dietary fat intake has been identified to increase renal $\mathrm{Ox}$ excretion ${ }^{(4,5)}$.

Besides urinary Ox concentration and excretion, further factors have been discussed as potential risk factors for the

\footnotetext{
Abbreviations: BW, body weight; $\mathrm{CaOx}$, calcium oxalate; CP, crude protien; HQ $35 \%$, high protein quality diet with $35 \%$ CP content; $\mathrm{HQ} 44 \%$, high protein quality diet with $44 \%$ CP content; HQ $57 \%$, high protein quality diet with $57 \%$ CP content; LQ $55 \%$, low protein quality diet with $55 \%$ CP content; Ox, oxalate; RSS, relative supersaturation.
}

* Corresponding author: Dr Nadine Paßlack, fax +49 3083855938, email nadine.passlack@fu-berlin.de 
development of $\mathrm{CaOx}$ uroliths in cats, including urinary volume, urinary $\mathrm{pH}$ and urinary $\mathrm{Ca}$ concentration and excretion. In general, a greater urinary volume lowers the total concentrations of $\mathrm{Ca}$ and $\mathrm{Ox}$ in the urine ${ }^{(6)}$, assuming that the renal excretion of $\mathrm{Ca}$ and $\mathrm{Ox}$ remains unchanged. Since increasing dietary protein concentrations were associated with increased water intake and a higher urinary volume in adult cats ${ }^{(7,8)}$ and kittens ${ }^{(9)}$, a moderate- or high-protein diet is considered to be beneficial in the treatment of cats with uroliths ${ }^{(10)}$.

A urinary $\mathrm{pH}<6.29$ is assumed to enhance the risk for the formation of $\mathrm{CaOx}$ uroliths in cats ${ }^{(11,12)}$, and the dietary protein concentration and source can modulate the $\mathrm{pH}$ of the urine. In one study, a high-protein diet (55\% crude protein (CP) on a DM basis), based on maize gluten meal, fish meal and soyabean meal, led to a urinary $\mathrm{pH}$ of 6.63 in cats, while feeding a moderate-protein diet (29\% CP on a DM basis) based on the same protein sources resulted in an alkaline urinary $\mathrm{pH}$ of $7 \cdot 25^{(13)}$. Another study in cats found also an alkaline urinary $\mathrm{pH}(>7)$ when feeding diets with moderate protein concentrations (29-32 \% CP on a DM basis) and meat meal, chicken meal or maize gluten meal as protein sources $^{(14)}$. However, the highest urinary $\mathrm{pH}$ (7.99) was found when feeding the diet based on meat meal, and the lowest $(7 \cdot 08)$ when feeding the diet with maize gluten meal ${ }^{(14)}$. In human subjects, especially a high intake of animal protein has been shown to result in an acid load ${ }^{(15)}$.

Interestingly, little is known about the impact of dietary protein concentration on renal $\mathrm{Ca}$ excretion in cats. For human subjects, a high intake of animal protein or particularly of sulfur-containing amino acids can be considered to be critical for the formation of $\mathrm{CaOx}$ uroliths, since an increased renal $\mathrm{Ca}$ excretion is associated ${ }^{(16,17)}$. This increase is often explained to be a result of an acid load, derived from the oxidation of sulfur-containing amino acids to sulfuric acid and the associated release of protons ${ }^{(18)}$. Moreover, the acid load does not only increase the renal excretion of $\mathrm{Ca}$, but also of uric acid, and decreases the renal excretion of citrate, all risk factors for the development of $\mathrm{CaOx}$ uroliths ${ }^{(15)}$. However, other authors found that the acid load may not solely be the reason for the increased renal $\mathrm{Ca}$ excretion associated with a high protein intake in human subjects ${ }^{(19,20)}$. In these studies, an increase in renal $\mathrm{Ca}$ excretion was observed even when adding the alkalising potassium bicarbonate or potassium citrate to a high-protein diet. Therefore, other factors may contribute to the increased renal $\mathrm{Ca}$ excretion, for instance a higher intestinal $\mathrm{Ca}$ absorption ${ }^{(21,22)}$. Moreover, since protein intake may modulate the secretion of $\mathrm{PG}^{(23)}$, an enhanced renal excretion of $\mathrm{PGE}_{2}$ could potentially regulate renal $\mathrm{Ca}$ excretion via the stimulation of calcitriol synthesis ${ }^{(24,25)}$.

Considering the sparse results on the relevance of dietary protein for the formation of $\mathrm{CaOx}$ uroliths in cats, the present study aimed to determine the effects of increasing dietary protein concentrations on feline urine composition in more detail. In addition, the impact of dietary protein quality has not been studied intensively. In one study by Zentek \& Schulz ${ }^{(2)}$, the highest urinary $\mathrm{Ox}$ concentrations in cats were observed when feeding a low-protein diet (23\% CP on a DM basis) based on collagen tissue when compared with low- and high-protein diets (22-64\% CP on a DM basis) based on horse meat or soya protein isolate. This effect could possibly be explained by the higher concentrations of hydroxyproline and glycine in collagen tissue ${ }^{(26)}$, which are precursors for endogenous Ox synthesis ${ }^{(6,27,28)}$. Surprisingly, in the Zentek \& Schulz study ${ }^{(2)}$, urinary Ox concentrations were lower when feeding a high-protein diet (78\% CP on a DM basis) based on collagen tissue when compared with the low-protein diet with collagen tissue as the protein source. Thus, the role of dietary protein quality for the formation of $\mathrm{CaOx}$ uroliths in cats needs further evaluation. The present study compared two diets with varying protein quality, characterised by different amounts of collagen-rich greaves meal in the diets. In contrast to the previous study ${ }^{(2)}$, the diets had comparable protein concentrations that allowed us to focus on the impact of protein quality as a single dietary factor on urine composition of cats.

\section{Materials and methods}

\section{Animal study}

The animal study was approved by the Animal Welfare Committee (Landesamt für Gesundheit und Soziales, Berlin, Germany, G 0004/08). A group of eight adult cats (European shorthair, four male, four female, aged 12-25 months) was included in the study. In total, four feeding periods were carried out, and each feeding period was divided into a $21 \mathrm{~d}$ adaptation period and a $7 \mathrm{~d}$ sampling period to allow for total urine and faeces collection. The cats were housed in groups (adaptation period) or individually (sampling period) in a room where a light (12 h light $-12 \mathrm{~h}$ darkness) and temperature $\left(20^{\circ} \mathrm{C}\right)$ regimen was kept constant at all times. All cats received socialisation throughout the study. The cats were fed once daily in the morning, while the constancy of body weight (BW) and the individual energy requirements of the cats were considered ${ }^{(29)}$. Water was provided ad libitum; however, since the water bowl for each cat was filled with $200 \mathrm{ml}$ water per d, a measurement of the daily water intake was possible. The individual daily feed and water intake of the cats was documented during each sampling period.

\section{Diets, water and proximate analysis}

Four extruded dry diets, varying in protein concentration and quality, were offered in four feeding periods. All cats were fed the same experimental diet at the same time (four-period, four-treatment parallel cross-over design).

The first three diets (HQ $35 \%$, HQ $44 \%$ and HQ $57 \%$ ) were characterised by high protein quality (HQ) and differed in CP concentration $(35,44$ and $57 \%$ on a DM basis). The fourth diet (LQ $55 \%$ ) had a comparable CP concentration (55\% on a DM basis) as diet HQ $57 \%$, but lower protein quality (LQ). Protein quality was based on the amount of collagen-rich ingredients included in the experimental diets, which was $11 \%$ greaves meal in diet HQ $57 \%$ and $34 \%$ greaves meal in diet LQ $55 \%$. The amount of greaves meal in the diets HQ $35 \%$ and HQ $44 \%$ was $10 \%$ and therefore comparable with diet HQ $57 \%$. 
All diets were formulated to fulfil the nutrient requirements of adult cats, according to the National Research Council ${ }^{(29)}$. The dietary components were selected to be low in $\mathrm{Ox}$ and the average dietary $\mathrm{Ox}$ concentrations were determined at 7 $\mathrm{mg} / 100 \mathrm{~g}$ on a DM basis, representing an average value obtained from analysis of three diets. The $\mathrm{Ca}$ concentrations were also comparable in all diets $(11 \cdot 0-12 \cdot 2 \mathrm{~g} / \mathrm{kg} \mathrm{DM})$. The ingredients of the experimental diets and the results of the proximate analysis of the diets are presented in the Tables 1 and 2. The analysis was performed as described elsewhere ${ }^{(30)}$. In brief, the concentrations of crude nutrients were measured according to the directions of the Weende analysis of feed ${ }^{(31)}$, with a modified method for the determination of crude fat ${ }^{(30)}$. The mineral concentrations in the diets were measured as described below for minerals in the faeces of the cats. Ox concentrations in the diets were analysed using a commercial oxalate oxidase assay (Enzytec ${ }^{\text {TM }}$ Oxalsäure, no. E2100; R-Biopharm AG). For each feed sample, $1 \mathrm{~g}$ was mixed with $4 \mathrm{ml}$ hydrochloric acid (5 M) for $15 \mathrm{~min}$ (Multi Reax; Heidolph Instruments $\mathrm{GmbH} \& \mathrm{Co}$.) and subsequently heated at $60^{\circ} \mathrm{C}$ for $3 \mathrm{~h}$ (Haake C10-W13; Thermo Scientific). The samples were centrifuged at $2663 \mathrm{~g}$ and room temperature for $15 \mathrm{~min}$ (Heraeus Labofuge 400R; Thermo Scientific), and the aqueous phase was filtered (SCFA Syringe Filter, $0.2 \mu \mathrm{m}$; Thermo Scientific). A quantity of $500 \mu \mathrm{l}$ of the filtered aqueous phase was adjusted to a $\mathrm{pH}$ of $2 \cdot 9-3 \cdot 1$, using either hydrochloric acid or sodium hydroxide. Subsequently, the samples were centrifuged at $17000 \mathrm{~g}$ and room temperature for $10 \mathrm{~min}$ (Heraeus Fresco 17 Centrifuge; Thermo Scientific). Then $10 \mu \mathrm{l}$ of the supernatant fraction and $200 \mu \mathrm{l}$ of Reagent 1 (Buffer, Enzytec ${ }^{\mathrm{TM}}$; R-Biopharm AG) were mixed for $1 \mathrm{~min}$ at $1050 \mathrm{rpm}$ and $37^{\circ} \mathrm{C}$ on an orbital shaker (BioShake iQ; Analytic Jena). After incubation for $5 \mathrm{~min}$ at $37^{\circ} \mathrm{C}$ and 590 nm (TECAN infinite M200 PRO; Tecan Group Ltd), $20 \mu \mathrm{l}$ of

Table 1. Ingredients (\%) of the experimental diets*

\begin{tabular}{lcccc}
\hline & \multicolumn{3}{c}{ High quality } & \\
\cline { 2 - 4 } Analysed & & & & \\
composition & HQ $35 \%$ & HQ $44 \%$ & HQ $57 \%$ & LQ $55 \%$ \\
\hline Maize & 44.2 & 32.7 & 9.43 & 19.2 \\
Poultry meal & 17.2 & 27.5 & 33.7 & 31.5 \\
Soya protein & 0.00 & 0.00 & 12.7 & 0.00 \\
Maize gluten & 9.51 & 11.6 & 17.0 & 0.00 \\
Greaves meal & 9.51 & 9.64 & 11.3 & 33.6 \\
Pig fat & 7.45 & 6.59 & 9.23 & 8.92 \\
Rice gluten & 2.85 & 2.89 & 0.00 & 0.00 \\
Dried beet pulp & 1.90 & 1.93 & 0.00 & 0.00 \\
Digest and & 3.93 & 3.83 & 3.85 & 3.85 \\
$\quad$ antioxidants & & & & \\
Salt & 0.91 & 0.86 & 0.90 & 0.58 \\
Yeast & 0.95 & 0.96 & 0.94 & 0.96 \\
Marigold meal & 0.03 & 0.03 & 0.03 & 0.03 \\
Minerals and vitamins & 1.56 & 1.47 & 0.92 & 1.36 \\
\hline
\end{tabular}

HQ $35 \%$, high protein quality diet with $35 \%$ crude protein content; HQ $44 \%$, high protein quality diet with $44 \%$ crude protein content; HQ $57 \%$, high protein quality diet with $57 \%$ crude protein content; LQ $55 \%$, low protein quality diet with $55 \%$ crude protein content.

* The quality differed depending on the amounts of collagen tissue in the diets: $\mathrm{HQ}$ $35 \%$ and HQ $44 \%, 10 \%$ greaves meal; HQ $57 \%, 11 \%$ greaves meal; LQ $55 \%$, $34 \%$ greaves meal.
Reagent 2 (oxalate oxidase, Enzytec ${ }^{\mathrm{TM}}$; R-Biopharm) were added. The samples were mixed for $1 \mathrm{~min}$ at $1050 \mathrm{rpm}$ and $37^{\circ} \mathrm{C}$ on an orbital shaker (BioShake iQ; Analytic Jena) and subsequently incubated at $37^{\circ} \mathrm{C}$ and $590 \mathrm{~nm}$ (TECAN infinite M200 PRO; Tecan Group Ltd). After $15 \mathrm{~min}$, extinctions were measured (TECAN infinite M200 PRO; Tecan Group Ltd), and Ox concentrations were calculated according to the instructions of the manufacturer (Enzytec ${ }^{\mathrm{TM}}$; R-Biopharm).

For the analysis of drinking water, the water sample was mixed with a specific buffer, where the buffer varied depending on the analysed minerals. For the measurement of $\mathrm{Zn}$ and $\mathrm{Cu}, 1 \mathrm{ml}$ water was mixed with $1 \mathrm{ml}$ of a buffer that was based on $10 \mathrm{ml} \mathrm{HCl}(37 \%)$ and $990 \mathrm{ml}$ ultra-pure water. For the measurement of Ca concentration, $0.05 \mathrm{ml}$ of the water sample and $4.95 \mathrm{ml}$ of a buffer $(10 \mathrm{ml} \mathrm{HCl} \mathrm{(37 \% ),} 20 \mathrm{ml}$ caesium chloride-lanthanum chloride buffer, $970 \mathrm{ml}$ ultra-pure water) were mixed. The caesium chloride buffer was based on $10 \mathrm{~g}$ caesium chloride/1 and $100 \mathrm{~g}$ lanthanum/1 (Merck KGaA). For the determination of $\mathrm{Na}$ concentration in the water, $0.025 \mathrm{ml}$ of the water sample and $4.975 \mathrm{ml}$ of a buffer $(10$ $\mathrm{ml} \mathrm{HCl}(37 \%), 50 \mathrm{ml}$ caesium chloride-lanthanum chloride buffer, $940 \mathrm{ml}$ ultra-pure water) were mixed. The sample for the $\mathrm{K}$ measurement was prepared using $0.05 \mathrm{ml}$ water and $4.95 \mathrm{ml}$ of a buffer $(10 \mathrm{ml} \mathrm{HCl} \mathrm{(37 \% ),} 50 \mathrm{ml}$ caesium chloride-lanthanum chloride buffer, $940 \mathrm{ml}$ ultra-pure water). For the determination of $\mathrm{Mg}$ concentration, $1 \mathrm{ml}$ of the water sample and $4 \mathrm{ml}$ of a buffer $(10 \mathrm{ml} \mathrm{HCl}(37 \%)$, $1 \mathrm{~g}$ potassium chloride, $990 \mathrm{ml}$ ultra-pure water) were mixed. Fe concentration was measured using a mixture of $1 \mathrm{ml}$ water and $1 \mathrm{ml}$ of a buffer $(10 \mathrm{ml} \mathrm{HCl} \mathrm{(37 \% ),} 1 \mathrm{~g}$ potassium chloride, $990 \mathrm{ml}$ ultra-pure water).

The concentrations of $\mathrm{Zn}, \mathrm{Cu}, \mathrm{Ca}, \mathrm{Na}, \mathrm{K}, \mathrm{Mg}$ and $\mathrm{Fe}$ in the prepared water samples were measured using atomic absorption spectrometry. For this, a flame atomic absorption spectrometer (type contra 700) with an autosampler (AS 52S) was used (Analytik Jena AG). For the analysis of P concentration in the water, $0.5 \mathrm{ml}$ of the water sample, $1.5 \mathrm{ml}$ ultra-pure water and $0.5 \mathrm{ml}$ of colour reagent (nitro-vanadate-molybdate solution) were mixed. After $10 \mathrm{~min}, \mathrm{P}$ concentration was measured spectrophotometrically ${ }^{(32)}$. The extinctions were determined with an Ultrospec 2100 pro Classic (Pharmacia Biotech) at a wavelength of $436 \mathrm{~nm}$.

\section{Collection, preparation and analysis of the urine and faeces}

During each sampling period, purpose-built cat litter boxes were used with plastic pellets as litter and connected urine collection containers to separate the urine from the faeces. Each urine collection container was provided with one drop of chlorhexidine digluconate to prevent bacterial growth in the urine. The cat litter boxes were checked for fresh urine and faeces three times per $\mathrm{d}$, and the samples were stored at $4^{\circ} \mathrm{C}$ until the evening. Urinary $\mathrm{pH}$ was measured in the evening with the Seven Multi pH meter (Mettler-Toledo $\mathrm{GmbH}$ ). After $\mathrm{pH}$ measurement, all urine and faeces samples of each day were stored at $-80^{\circ} \mathrm{C}$ (urine) or $-20^{\circ} \mathrm{C}$ (faeces) until further analysis. Sample preparation and analysis were as described elsewhere ${ }^{(33)}$. In short, the concentrations of urinary anions (sulfate and 
Table 2. Nutrient analysis of the experimental diets*

\begin{tabular}{|c|c|c|c|c|}
\hline \multirow[b]{2}{*}{ Analysed composition } & \multicolumn{3}{|c|}{ High quality } & \multirow{2}{*}{$\frac{\text { Low quality }}{\text { LQ } 55 \%}$} \\
\hline & HQ $35 \%$ & HQ $44 \%$ & HQ $57 \%$ & \\
\hline $\mathrm{DM}(\mathrm{g} / \mathrm{kg})$ & 904 & 919 & 923 & 928 \\
\hline Crude protein (g/kg DM) & 347 & 438 & 574 & 547 \\
\hline Crude fat (g/kg DM) & 115 & 124 & 171 & 183 \\
\hline Crude fibre (g/kg DM) & $11 \cdot 1$ & $22 \cdot 8$ & $10 \cdot 8$ & 11.9 \\
\hline Crude ash (g/kg DM) & $72 \cdot 8$ & $67 \cdot 7$ & 71.4 & $72 \cdot 3$ \\
\hline $\mathrm{Ca}(\mathrm{g} / \mathrm{kg} \mathrm{DM})$ & $12 \cdot 2$ & 11.3 & 11.4 & 11.0 \\
\hline$P(g / k g ~ D M)$ & 11.3 & 11.0 & $12 \cdot 3$ & 11.4 \\
\hline $\mathrm{Na}(\mathrm{g} / \mathrm{kg} \mathrm{DM})$ & 7.40 & $6 \cdot 51$ & 7.52 & 7.72 \\
\hline $\mathrm{K}(\mathrm{g} / \mathrm{kg} \mathrm{DM})$ & $6 \cdot 30$ & 5.24 & 7.36 & 6.97 \\
\hline $\mathrm{Cl}$ (g/kg DM) & 11.6 & 9.50 & 8.34 & $10 \cdot 7$ \\
\hline $\mathrm{Mg}(\mathrm{g} / \mathrm{kg} \mathrm{DM})$ & 1.08 & $1 \cdot 12$ & 1.36 & 0.89 \\
\hline ME (MJ/kg DM)† & $17 \cdot 0$ & $17 \cdot 2$ & $18 \cdot 6$ & $18 \cdot 8$ \\
\hline NFE (g/kg DM)‡ & 454 & 348 & 173 & 186 \\
\hline
\end{tabular}

HQ $35 \%$, high protein quality diet with $35 \%$ crude protein content; HQ $44 \%$, high protein quality diet with $44 \%$ crude protein content; HQ $57 \%$, high protein quality diet with $57 \%$ crude protein content; LQ $55 \%$, low protein quality diet with $55 \%$ crude protein content; ME, metabolisable energy; NFE, N-free extracts.

* The quality differed depending on the amounts of collagen tissue in the diets: HQ $35 \%$ and HQ $44 \%, 10 \%$ greaves meal; HQ $57 \%, 11 \%$ greaves meal; LQ $55 \%, 34 \%$ greaves meal.

$\dagger$ Calculated according to the National Research Council ${ }^{(29)}$ using the four-step calculation with due regard to the crude fibre concentrations of the diets

$\ddagger$ Calculated as follows: NFE = DM - (crude ash + crude protein + crude fat + crude fibre).

phosphate as major anions; $\mathrm{Ox}$ and citrate as minor anions) were measured with an ion exchange HPLC system (Dionex DX-500; Dionex Corp.), and also the concentrations of urinary cations ( $\mathrm{Na}$ and $\mathrm{K}$ as major cations; $\mathrm{Mg}$ and $\mathrm{Ca}$ as minor cations) (Dionex DX-120). Data on the concentrations of urinary anions and cations were analysed using Chromeleon Client, version $6.80 \mathrm{SP} 2$ (Dionex Corp.). The $\mathrm{Cl}$ concentrations in the faeces of the cats were determined using an ion exchange HPLC system (Dionex DX-500; Dionex Corp.). Faecal P concentrations were measured spectrophotometrically ${ }^{(32)}$ (Ultrospec 2000, Pharmacia Biotech), and the concentrations of $\mathrm{Ca}, \mathrm{Na}$, $\mathrm{K}$ and $\mathrm{Mg}$ in the faeces were measured using atomic absorption spectrometry (flame atomic absorption spectrometer type vario 6 with an autosampler AS 52; Analytik Jena AG). The urinary $\mathrm{CaOx}$ relative supersaturation (RSS $\mathrm{CaOx}$ ) was calculated using the Supersat Program ${ }^{(34)}$.

\section{Renal and faecal excretion, apparent digestibility and retention}

Renal excretion of the anions and cations was calculated as follows:

Renal excretion $(\mathrm{mg} / \mathrm{kg} \mathrm{BW}$ per $\mathrm{d})=$ (anion or cation concentration in the urine $(\mathrm{mg} / \mathrm{ml}) \times$ total urinary volume $(\mathrm{ml} / \mathrm{d})) / \mathrm{BW}(\mathrm{kg})$.

Faecal excretion of the minerals was calculated as follows:

Faecal excretion $(\mathrm{mg} / \mathrm{kgBW}$ per $\mathrm{d})=($ mineral concentration in the faeces $(\mathrm{mg} / \mathrm{g} \mathrm{DM}) \times$ total amount of faeces $(\mathrm{g} \mathrm{DM} / \mathrm{d})) / \mathrm{BW}(\mathrm{kg})$.

The apparent digestibility of the minerals was calculated with:

Apparent digestibility $(\%)=($ mineral intake $(\mathrm{mg} / \mathrm{d})-$ faecal mineral excretion $(\mathrm{mg} / \mathrm{d})) /$ mineral intake $(\mathrm{mg} / \mathrm{d}) \times 100$.

Apparent digestibility of CP was calculated by analogy.
Mineral retention was calculated as follows:

Mineral retention $(\mathrm{mg} / \mathrm{d})=$ mineral intake $(\mathrm{mg} / \mathrm{d})-$ renal mineral excretion $(\mathrm{mg} / \mathrm{d})$ - faecal mineral excretion $(\mathrm{mg} / \mathrm{d})$.

\section{Statistical analysis}

For the statistical analysis, the impact of a varying dietary protein concentration (diets HQ $35 \%$, HQ $44 \%$, HQ $57 \%$ ) and of a varying dietary protein quality (diet HQ $57 \% v$. diet LQ $55 \%$ ) was separately evaluated. For this, SPSS 15 (SPSS Inc.) was used. A repeated-measures ANOVA was performed (fixed factor protein concentration or protein quality), and withinsubject contrasts (simple contrasts; protein concentration $=$ three levels and protein quality = two levels; three tests per parameter for protein concentration and one test per parameter for protein quality) were considered for the detection of group differences. The data are presented in tables as mean values with their standard errors. Significant differences $(P \leq 0 \cdot 05)$ among groups (separate for the comparisons of dietary protein concentration and dietary protein quality) are shown.

\section{Results}

\section{Composition of drinking water}

The analysed mineral concentrations in the drinking water were: $106 \mathrm{mg} \mathrm{Ca} / 1,37.8 \mathrm{mg} \mathrm{Na} / 1,10.9 \mathrm{mg} \mathrm{K} / 1,8.80 \mathrm{mg}$ $\mathrm{Mg} / \mathrm{l}, 0.58 \mathrm{mg} \mathrm{Cu} / 1,0.03 \mathrm{mg} \mathrm{Zn/1} \mathrm{and} 0.01 \mathrm{mg} \mathrm{Fe} / \mathrm{l}$. The $\mathrm{P}$ concentration in the water was below the detection limit (1.33 mg/l).

\section{Animal health, body weight, feed and water intake, urinary volume and urinary $\mathrm{pH}$}

All cats were healthy throughout the study. The BW of the cats did not differ when receiving diets with different protein quality (HQ $57 \% v$. LQ $55 \%$ ), and showed small variations with 
differing dietary protein concentrations (HQ $35 \%$, HQ $44 \%$, HQ $57 \%$ ) (Table 3). The varying dietary protein quality had no impact on daily feed and water intake, urinary volume or urinary $\mathrm{pH}$ (Table 3). In contrast, increasing concentrations of dietary protein led to an increased urinary volume and a higher feed intake. Urinary $\mathrm{pH}$ was the lowest $(6 \cdot 34)$ after feeding diet HQ $44 \%$ when compared with the diets HQ $35 \%(6.66)$ and HQ $57 \%(6.61)$.

\section{Effect of dietary protein concentration}

Impact on urinary concentration and excretion of calcium and oxalate and the urinary relative supersaturation with calcium oxalate. Urinary $\mathrm{Ca}$ concentrations and renal $\mathrm{Ca}$ excretion increased with increasing dietary protein concentrations (Table 4). Urinary Ox concentration was the lowest after feeding diet HQ $57 \%$ when compared with the diets HQ $35 \%$ and HQ $44 \%$; however, calculating renal Ox excretion demonstrated an increase from $1.08 \mathrm{mg} / \mathrm{kg}$ BW per d (HQ $35 \%$ ) to $1.68 \mathrm{mg} / \mathrm{kg}$ BW per d (HQ $57 \%$ ). Urinary RSS $\mathrm{CaOx}$ also increased with increasing protein concentrations in the diets, reaching values between 8.24 (HQ $35 \%$ ) and 11.2 (HQ $57 \%$ ) (Table 3).

Impact on urinary concentration and excretion of sodium, potassium, phosphorus, magnesium, citrate and sulfate Urinary $\mathrm{Na}$ and $\mathrm{K}$ concentrations were the lowest in the group that received diet HQ $57 \%$ when compared with the diets HQ $35 \%$ and HQ $44 \%$; however, calculating the renal excretion of these minerals demonstrated contrary results (Table 4). While urinary $\mathrm{P}$ concentrations were unaffected by dietary protein concentrations, renal $\mathrm{P}$ excretion increased with increasing protein in the diets. Urinary $\mathrm{Mg}$ concentrations and renal $\mathrm{Mg}$ excretion varied among the groups, while no unidirectional effect of protein concentration in the diet could be observed. Urinary citrate concentrations were markedly higher after feeding diet HQ $35 \%(148 \mathrm{mg} / \mathrm{l})$ when compared with the other groups $(65 \cdot 0-80 \cdot 8 \mathrm{mg} / \mathrm{l})$; however, based on daily renal citrate excretion, the amounts were comparable between the groups
HQ $35 \%$ and HQ $57 \%$, but lower in group HQ $44 \%$. Urinary sulfate concentrations were not affected by the protein concentration in the diet, while renal sulfate excretion increased with increasing dietary protein concentrations.

Impact on amount and DM of the faeces, faecal mineral concentrations and excretion. The daily amount of faeces on a DM basis was the lowest in group HQ $44 \%$ when compared with the other groups, and the DM concentration of the faeces decreased with increasing dietary protein (Table 5).

The protein concentration of the diets affected mineral concentrations in the faeces of the cats; however, no unidirectional effect could be detected (Table 5). The lowest faecal $\mathrm{Ca}, \mathrm{P}, \mathrm{Mg}$ and $\mathrm{Na}$ concentrations, but the highest faecal $\mathrm{K}$ concentrations, were observed in group HQ $44 \%$ when compared with the other groups. $\mathrm{Cl}$ concentrations in the faeces of the cats did not differ among the groups. The described observations also applied for faecal $\mathrm{Ca}, \mathrm{P}, \mathrm{Mg}$ and $\mathrm{Na}$ excretion, while faecal $\mathrm{K}$ and $\mathrm{Cl}$ excretion was unaffected by dietary protein concentration (Table 5).

Impact on apparent digestibility and mineral retention. The apparent digestibility of CP was the lowest in group HQ $35 \%$ when compared with the groups HQ $44 \%$ and HQ $57 \%$ (Table 6). As described for the mineral concentrations in the faeces of the cats, no unidirectional effect of protein concentration in the diet could be observed for the apparent digestibility and the retention of the minerals. The highest apparent digestibility of $\mathrm{Ca}, \mathrm{P}$ and $\mathrm{Mg}$, but the lowest apparent digestibility of $\mathrm{K}$, was observed in group HQ $44 \%$ when compared with the other groups. The apparent digestibility of $\mathrm{Na}$ and $\mathrm{Cl}$ did not differ among the groups. The retention of $\mathrm{Ca}, \mathrm{P}$ and $\mathrm{Mg}$ was the highest, and the retention of $\mathrm{Na}$ and $\mathrm{K}$ was the lowest, in group HQ $44 \%$ when compared with the groups HQ $35 \%$ and HQ $57 \%$ (Table 6).

Table 3. Body weight (BW), feed and water intake, urinary volume, urinary $\mathrm{pH}$ and urinary relative supersaturation with calcium oxalate (RSS CaOx) of cats fed a diet with a varying protein concentration and quality (Mean values with their standard errors; $n 8$ per diet)

\begin{tabular}{|c|c|c|c|c|c|c|c|}
\hline & \multicolumn{4}{|c|}{ Protein concentration } & \multicolumn{3}{|c|}{ Protein quality* } \\
\hline & HQ $35 \%$ & HQ $44 \%$ & HQ $57 \%$ & SEM & HQ $57 \%$ & LQ $55 \%$ & SEM \\
\hline $\mathrm{BW}(\mathrm{kg})$ & $4.07^{\mathrm{b}}$ & $3.99^{a}$ & $4 \cdot 17^{\mathrm{b}}$ & 0.30 & $4 \cdot 17$ & 4.22 & 0.36 \\
\hline Feed intake (g DM/kg BW per d) & $13 \cdot 3^{a}$ & $13 \cdot 3^{a, b}$ & $16 \cdot 0^{\mathrm{b}}$ & 0.83 & $16 \cdot 0$ & $13 \cdot 4$ & 1.03 \\
\hline Water intake (ml/kg BW per d) & $29 \cdot 8$ & 29.8 & 35.4 & 1.79 & $35 \cdot 4$ & 32.5 & 1.77 \\
\hline Urinary volume $(\mathrm{ml} / \mathrm{kg}$ BW per $\mathrm{d})$ & $9 \cdot 86^{\mathrm{a}}$ & $10 \cdot 9^{a}$ & $17 \cdot 0^{\mathrm{b}}$ & 1.03 & $17 \cdot 0$ & 14.7 & 1.05 \\
\hline Urinary $\mathrm{pH}$ & $6 \cdot 66^{\mathrm{b}}$ & $6 \cdot 34^{\mathrm{a}}$ & $6 \cdot 61^{\mathrm{b}}$ & 0.04 & $6 \cdot 61$ & 6.58 & 0.02 \\
\hline Urinary RSS CaOx & $8 \cdot 24^{\mathrm{a}}$ & $10 \cdot 9^{\mathrm{b}}$ & $11 \cdot 2^{\mathrm{b}}$ & 0.80 & $11 \cdot 2$ & $10 \cdot 1$ & 0.94 \\
\hline
\end{tabular}

HQ $35 \%$, high protein quality diet with $35 \%$ crude protein content; HQ $44 \%$, high protein quality diet with $44 \%$ crude protein content; HQ $57 \%$, high protein quality diet with $57 \%$ crude protein content; LQ $55 \%$, low protein quality diet with $55 \%$ crude protein content.

a,b Mean values within a row with unlike superscript letters were significantly different $(P \leq 0.05)$.

* Protein quality differed depending on the amounts of greaves meal in the diets: HQ $35 \%$ and HQ $44 \%, 10 \%$ greaves meal; HQ $57 \%, 11 \%$ greaves meal; LQ $55 \%, 34 \%$ greaves meal. 
Table 4. Urinary concentration and renal excretion of anions and cations of cats fed a diet with a varying protein concentration and quality (Mean values with their standard errors; $n 8$ per diet)

\begin{tabular}{|c|c|c|c|c|c|c|c|}
\hline & \multicolumn{4}{|c|}{ Protein concentration } & \multicolumn{3}{|c|}{ Protein quality $\dagger$} \\
\hline & HQ $35 \%$ & $\mathrm{HQ} 44 \%$ & HQ $57 \%$ & SEM & HQ $57 \%$ & LQ $55 \%$ & SEM \\
\hline \multicolumn{8}{|c|}{ Urinary concentration $(\mathrm{mg} / \mathrm{l})$} \\
\hline $\mathrm{Ca}$ & $60 \cdot 5^{a}$ & $59 \cdot 4^{a}$ & $78 \cdot 3^{b}$ & 4.32 & $78 \cdot 3$ & 68.0 & $5 \cdot 16$ \\
\hline$P$ & 2880 & 2658 & 2608 & 178 & 2608 & 2557 & 207 \\
\hline $\mathrm{Mg}$ & $33.0^{\mathrm{a}}$ & $47 \cdot 6^{\mathrm{b}}$ & $29 \cdot 9^{a}$ & 3.08 & 29.9 & $25 \cdot 0$ & 3.25 \\
\hline $\mathrm{K}$ & $2165^{b}$ & $2009^{b}$ & $1773^{a}$ & 107 & 1773 & 1994 & 124 \\
\hline $\mathrm{Na}$ & $2443^{b}$ & $1990^{a, b}$ & $1947^{\mathrm{a}}$ & 139 & 1947 & 2162 & 181 \\
\hline Ox & $118^{\mathrm{b}}$ & $135^{b}$ & $102^{\mathrm{a}}$ & 7.53 & 102 & 104 & 5.72 \\
\hline Sulfate & 3277 & 3664 & 3548 & 293 & 3548 & $2911^{*}$ & 317 \\
\hline Citrate & $148^{\mathrm{b}}$ & $65 \cdot 0^{\mathrm{a}}$ & $80 \cdot 8^{a}$ & $16 \cdot 8$ & $80 \cdot 8$ & 67.0 & $12 \cdot 2$ \\
\hline \multicolumn{8}{|c|}{ Renal excretion (mg/kg BW per d) } \\
\hline $\mathrm{Ca}$ & $0.59^{\mathrm{a}}$ & $0.69^{a}$ & $1 \cdot 32^{\mathrm{b}}$ & $0 \cdot 10$ & 1.32 & $0.98^{*}$ & 0.12 \\
\hline $\mathrm{P}$ & $27 \cdot 3^{\mathrm{a}}$ & $30 \cdot 3^{a, b}$ & $43 \cdot 8^{b}$ & 3.06 & 43.8 & $34 \cdot 7$ & 3.16 \\
\hline $\mathrm{Mg}$ & $0.30^{a}$ & $0.54^{\mathrm{a}, \mathrm{b}}$ & $0.50^{\mathrm{b}}$ & 0.04 & 0.50 & 0.35 & 0.05 \\
\hline $\mathrm{K}$ & $20 \cdot 3^{a}$ & $22 \cdot 2^{\mathrm{a}, \mathrm{b}}$ & $29 \cdot 7^{b}$ & 1.91 & $29 \cdot 7$ & $28 \cdot 2$ & $2 \cdot 23$ \\
\hline $\mathrm{Na}$ & $22 \cdot 2^{a}$ & $21 \cdot 6^{\mathrm{a}}$ & $32 \cdot 3^{b}$ & 1.65 & $32 \cdot 3$ & 29.7 & $2 \cdot 32$ \\
\hline Ox & $1.08^{\mathrm{b}}$ & $1.51^{\mathrm{a}, \mathrm{b}}$ & $1.68^{\mathrm{a}}$ & 0.10 & 1.68 & 1.48 & 0.10 \\
\hline Sulfate & $30 \cdot 6^{\mathrm{a}}$ & $43 \cdot 5^{\mathrm{a}, \mathrm{b}}$ & $59 \cdot 4^{\mathrm{b}}$ & $5 \cdot 18$ & 59.4 & 39.0 & $5 \cdot 50$ \\
\hline Citrate & $1 \cdot 20^{\mathrm{b}}$ & $0.64^{\mathrm{a}}$ & $1.29^{b}$ & 0.13 & 1.29 & 0.89 & $0 \cdot 16$ \\
\hline
\end{tabular}

HQ $35 \%$, high protein quality diet with $35 \%$ crude protein content; HQ $44 \%$, high protein quality diet with $44 \%$ crude protein content; HQ $57 \%$, high protein quality diet with $57 \%$ crude protein content; LQ $55 \%$, low protein quality diet with $55 \%$ crude protein content; BW, body weight.

a,b Mean values within a row with unlike superscript letters were significantly different $(P \leq 0.05)$.

* Mean value was significantly different from that for $\mathrm{HQ} 57 \%(P \leq 0.05)$.

† Protein quality differed depending on the amounts of greaves meal in the diets: HQ $35 \%$ and HQ $44 \%, 10 \%$ greaves meal; HQ $57 \%, 11 \%$ greaves meal; LQ $55 \%$, $34 \%$ greaves meal.

\section{Effect of dietary protein quality}

Impact on urinary concentration and excretion of calcium and oxalate and urinary relative supersaturation with calcium oxalate. The protein quality of the diets did not influence the total concentrations of $\mathrm{Ca}$ and $\mathrm{Ox}$ in the urine of the cats, renal Ox excretion or urinary RSS CaOx values (Tables 3 and 4). However, renal $\mathrm{Ca}$ excretion was higher when feeding the diet with the lower amounts of greaves meal (HQ $57 \%$ ).

Table 5. Amount of faeces, DM of the faeces, mineral concentrations in the faeces and faecal mineral excretion of cats fed a diet with a varying protein concentration and quality (Mean values with their standard errors; $n 8$ per diet)

\begin{tabular}{|c|c|c|c|c|c|c|c|}
\hline & \multicolumn{4}{|c|}{ Protein concentration } & \multicolumn{3}{|c|}{ Protein quality $\dagger$} \\
\hline & HQ $35 \%$ & HQ $44 \%$ & HQ $57 \%$ & SEM & HQ $57 \%$ & LQ $55 \%$ & SEM \\
\hline Amount of faeces ( $\mathrm{g} / \mathrm{kg} \mathrm{BW}$ per d) & $5 \cdot 25^{a}$ & $4.46^{\mathrm{a}}$ & $7 \cdot 35^{\mathrm{b}}$ & 0.53 & $7 \cdot 35$ & 5.74 & 0.64 \\
\hline DM of the faeces $(\%)$ & $44 \cdot 2^{a, b}$ & $42 \cdot 4^{\mathrm{b}}$ & $39 \cdot 3^{a}$ & 0.83 & 39.3 & 49.0 & $2 \cdot 23$ \\
\hline Amount of faeces (g DM/kg BW per d) & $2 \cdot 33^{\mathrm{b}}$ & $1.85^{\mathrm{a}}$ & $2 \cdot 83^{\mathrm{b}}$ & 0.19 & 2.83 & 2.88 & 0.31 \\
\hline \multicolumn{8}{|l|}{ Faecal concentrations (mg/g DM) } \\
\hline $\mathrm{Ca}$ & $72 \cdot 1^{\mathrm{b}}$ & $63.0^{a}$ & $77 \cdot 2^{\mathrm{b}}$ & 1.62 & 77.2 & $68 \cdot 2^{*}$ & 2.06 \\
\hline $\mathrm{P}$ & $48 \cdot 8^{\mathrm{b}}$ & $33.2^{\mathrm{a}}$ & $50.9^{b}$ & 1.81 & 50.9 & $41 \cdot 1^{*}$ & 1.44 \\
\hline $\mathrm{Mg}$ & $6 \cdot 10^{\mathrm{b}}$ & $5 \cdot 24^{\mathrm{a}}$ & $7 \cdot 12^{\mathrm{b}}$ & 0.20 & $7 \cdot 12$ & $4.72^{*}$ & 0.35 \\
\hline $\mathrm{K}$ & $2 \cdot 16^{\mathrm{a}}$ & $4.48^{b}$ & $2.36^{\mathrm{a}}$ & 0.37 & 2.36 & $1.08^{*}$ & 0.28 \\
\hline $\mathrm{Na}$ & $2 \cdot 13^{b}$ & $1.98^{\mathrm{a}}$ & $2 \cdot 35^{\mathrm{b}}$ & 0.13 & 2.35 & $2 \cdot 21$ & 0.15 \\
\hline $\mathrm{Cl}$ & 1.50 & 1.64 & 1.78 & 0.21 & 1.78 & 1.35 & 0.27 \\
\hline \multicolumn{8}{|l|}{ Faecal excretion (mg/kg BW per d) } \\
\hline $\mathrm{Ca}$ & $167^{b}$ & $117^{\mathrm{a}}$ & $224^{\mathrm{C}}$ & $16 \cdot 9$ & 224 & $166^{*}$ & $21 \cdot 5$ \\
\hline$P$ & $112^{\mathrm{b}}$ & $62 \cdot 2^{\mathrm{a}}$ & $144^{\mathrm{b}}$ & $10 \cdot 8$ & 144 & 115 & 12.5 \\
\hline $\mathrm{Na}$ & $5 \cdot 27^{\mathrm{a}, \mathrm{b}}$ & $3.70^{\mathrm{a}}$ & $6.93^{\mathrm{b}}$ & 0.68 & 6.93 & 6.65 & 1.07 \\
\hline $\mathrm{Mg}$ & $14 \cdot 3^{\mathrm{b}}$ & $9 \cdot 76^{\mathrm{a}}$ & $20 \cdot 1^{b}$ & 1.49 & $20 \cdot 1$ & $13 \cdot 2^{*}$ & 1.77 \\
\hline $\mathrm{K}$ & 5.91 & 8.91 & $7 \cdot 27$ & $1 \cdot 14$ & $7 \cdot 27$ & $2.94^{*}$ & $1 \cdot 10$ \\
\hline $\mathrm{Cl}$ & 3.69 & 3.32 & 5.58 & 0.77 & 5.58 & 4.11 & 1.12 \\
\hline
\end{tabular}

$\mathrm{HQ} 35 \%$, high protein quality diet with $35 \%$ crude protein content; $\mathrm{HQ} 44 \%$, high protein quality diet with $44 \%$ crude protein content; $\mathrm{HQ} 57 \%$, high protein quality diet with $57 \%$ crude protein content; LQ $55 \%$, low protein quality diet with $55 \%$ crude protein content; BW, body weight.

a,b,c Mean values within a row with unlike superscript letters were significantly different $(P \leq 0.05)$.

${ }^{*}$ Mean value was significantly different from that for $\mathrm{HQ} 57 \%(P \leq 0.05)$.

† Protein quality differed depending on the amounts of greaves meal in the diets: HQ $35 \%$ and HQ $44 \%, 10 \%$ greaves meal; HQ $57 \%, 11 \%$ greaves meal; LQ $55 \%, 34 \%$ greaves meal. 
Table 6. Apparent digestibility of crude protein (CP) and minerals, and mineral retention of cats fed a diet with a varying protein concentration and quality (Mean values with their standard errors; $n 8$ per diet)

\begin{tabular}{|c|c|c|c|c|c|c|c|}
\hline & \multicolumn{4}{|c|}{ Protein concentration } & \multicolumn{3}{|c|}{ Protein quality $†$} \\
\hline & HQ $35 \%$ & HQ $44 \%$ & HQ $57 \%$ & SEM & HQ $57 \%$ & LQ $55 \%$ & SEM \\
\hline \multicolumn{8}{|c|}{ Apparent digestibility (\%) } \\
\hline $\mathrm{CP}$ & $83 \cdot 3^{a}$ & $88 \cdot 7^{\mathrm{b}}$ & $87 \cdot 6^{\mathrm{b}}$ & 0.80 & 87.6 & 82.9 & 1.60 \\
\hline $\mathrm{Ca}$ & $0.09^{a}$ & $22 \cdot 5^{\mathrm{b}}$ & $-19 \cdot 1^{\mathrm{a}}$ & 5.46 & $-19 \cdot 1$ & $-16 \cdot 2$ & 5.46 \\
\hline $\mathrm{P}$ & $27 \cdot 1^{a}$ & $57 \cdot 6^{\mathrm{b}}$ & $27 \cdot 2^{a}$ & 3.90 & $27 \cdot 2$ & 23.5 & 3.90 \\
\hline $\mathrm{Na}$ & $95 \cdot 0$ & $95 \cdot 7$ & $94 \cdot 3$ & 0.42 & $94 \cdot 3$ & 93.6 & 0.42 \\
\hline $\mathrm{Mg}$ & $4 \cdot 73^{a}$ & $34.4^{\mathrm{b}}$ & $7 \cdot 60^{\mathrm{a}}$ & 4.68 & 7.60 & $-11 \cdot 1$ & 4.68 \\
\hline K & $93 \cdot 6^{\mathrm{b}}$ & $87 \cdot 5^{a}$ & $94 \cdot 1^{\mathrm{b}}$ & 1.29 & $94 \cdot 1$ & $96 \cdot 5$ & 1.29 \\
\hline $\mathrm{Cl}$ & $97 \cdot 7$ & 97.4 & $96 \cdot 0$ & 0.51 & $96 \cdot 0$ & $97 \cdot 2$ & 0.51 \\
\hline \multicolumn{8}{|c|}{ Retention (mg/d) } \\
\hline $\mathrm{Ca}$ & $-4.92^{a}$ & $98 \cdot 8^{b}$ & $-32 \cdot 6^{a, b}$ & $43 \cdot 3$ & $-32 \cdot 6$ & $-81 \cdot 0$ & $69 \cdot 1$ \\
\hline $\mathrm{P}$ & $43 \cdot 8^{a}$ & $172^{b}$ & $28 \cdot 1^{a}$ & 23.7 & $28 \cdot 1$ & $11 \cdot 1$ & $32 \cdot 7$ \\
\hline $\mathrm{Na}$ & $267^{\mathrm{b}}$ & $213^{a}$ & $313^{c}$ & 15.5 & 313 & 269 & $19 \cdot 4$ \\
\hline $\mathrm{Mg}$ & $0.90^{\mathrm{a}}$ & $14 \cdot 2^{\mathrm{b}}$ & $4 \cdot 20^{a, b}$ & $2 \cdot 90$ & $4 \cdot 20$ & $-4 \cdot 72$ & 3.99 \\
\hline $\mathrm{K}$ & $217^{b}$ & $131^{\mathrm{a}}$ & $313^{\mathrm{c}}$ & 18.7 & 313 & $247^{\star}$ & $20 \cdot 0$ \\
\hline
\end{tabular}

HQ $35 \%$, high protein quality diet with $35 \%$ crude protein content; HQ $44 \%$, high protein quality diet with $44 \%$ crude protein content; HQ $57 \%$, high protein quality diet with $57 \%$ crude protein content; LQ $55 \%$, low protein quality diet with $55 \%$ crude protein content.

a,b,c Mean values within a row with unlike superscript letters were significantly different $(P \leq 0.05)$.

* Mean value was significantly different from that for $\mathrm{HQ} 57 \%(P \leq 0.05)$.

† Protein quality differed depending on the amounts of greaves meal in the diets: HQ $35 \%$ and HQ $44 \%, 10 \%$ greaves meal; HQ $57 \%, 11 \%$ greaves meal; LQ $55 \%, 34 \%$ greaves meal.

Impact on urinary concentration and excretion of sodium, potassium, phosphorus, magnesium, citrate and sulfate.

The protein quality of the diets did not affect the concentrations of $\mathrm{P}, \mathrm{Mg}, \mathrm{Na}$ and $\mathrm{K}$ in the urine of the cats or the renal excretion of these minerals (Table 4). Urinary sulfate concentrations were lower in group LQ $55 \%$ when compared with group HQ $57 \%$; however, renal sulfate excretion did not differ between the groups. Urinary citrate concentrations and renal citrate excretion were not affected by a different protein quality of the diets.

Impact on amount and DM of faeces, faecal mineral concentrations and excretion. The protein quality of the diets did not affect the daily amount of faeces of the cats or the faecal DM concentration (Table 5). Faecal Ca, P, Mg and $\mathrm{K}$ concentrations were lower in group LQ $55 \%$ when compared with group HQ $57 \%$, while this effect was also observed for faecal $\mathrm{Ca}, \mathrm{Mg}$ and $\mathrm{K}$ excretion (Table 5). Faecal $\mathrm{Na}$ and $\mathrm{Cl}$ concentrations and excretion were not affected by the varying amount of greaves meal in the diets.

Impact on apparent digestibility and mineral retention. The apparent digestibility of CP was approximately $5 \%$ lower in group LQ $55 \%$ when compared with group HQ $57 \%$; however, this difference was not statistically significant $(P>$ 0.05) (Table 6). The protein quality of the diets did not affect the apparent digestibility or the retention of the minerals (Table 6). The only exception was $\mathrm{K}$ retention, which was higher in group HQ $57 \%$ when compared with group LQ $55 \%$.

\section{Discussion}

The present study was conducted to investigate the hypothesis that a high-protein diet can be considered as a risk factor for the formation of $\mathrm{CaOx}$ uroliths in cats. While this is the scientific consensus in human subjects, since an increase in renal $\mathrm{Ca}$ and $\mathrm{Ox}$ excretion has been associated with a high protein intake $e^{(1,17)}$, previous studies have indicated that a high-protein diet could be beneficial for the prevention of $\mathrm{CaOx}$ uroliths in cats $^{(2,3,10,35)}$. However, these studies were based on an epidemiological risk evaluation ${ }^{(35)}$ or have only focused on the effects of dietary protein on the urinary volume ${ }^{(10)}$ and urinary Ox excretion ${ }^{(2,3)}$, while other risk factors for the formation of $\mathrm{CaOx}$ uroliths were not considered.

Urinary Ox concentrations in the present study were the lowest when feeding the high-protein diet (HQ $57 \%$ ); however, no strict decrease with increasing dietary protein concentrations could be detected, since the group that received the medium-protein diet (HQ $44 \%$ ) showed the highest urinary Ox concentrations and the difference between the low (HQ $35 \%$ )- and high-protein group was small. In contrast, a unidirectional increase in renal $\mathrm{Ox}$ excretion was observed with increasing dietary protein concentrations. It can be assumed that the lower urinary $\mathrm{Ox}$ concentrations did result from the increase in the urinary volume associated with the high-protein diet. In general, it could be supposed that a lower urinary $\mathrm{Ox}$ concentration is of higher relevance than the increase in renal $\mathrm{Ox}$ excretion with regard to $\mathrm{CaOx}$ urolith formation. However, in this context, the calculated RSS CaOx values should not go unmentioned. We observed an increase in urinary RSS $\mathrm{CaOx}$ with increasing dietary protein concentrations, indicating that a high-protein diet may be critical for the formation of $\mathrm{CaOx}$ uroliths in cats and that the increase in renal Ox excretion with increasing dietary protein concentrations should not be undervalued.

The increased renal Ox excretion can possibly be explained by an enhanced endogenous $\mathrm{Ox}$ synthesis. In general, the amounts of $\mathrm{Ox}$ in cat food are considered to be small ${ }^{(6)}$ and the average $\mathrm{Ox}$ concentration in the present diets was 
determined at $7 \mathrm{mg} / 100 \mathrm{~g}$ DM. Food components that are rich in Ox include vegetables and grain, moderate Ox concentrations are found in cereals and nuts, and only low amounts in food of animal origin like meat, milk products and fish ${ }^{(36,37)}$. In a previous study ${ }^{(3)}$, renal Ox excretion was not affected by a high-protein diet based on casein. However, the authors concluded that this effect may be different in the case of another protein source. In the present study, the main protein source was poultry meal. Since poultry meal is often used for commercial cat food, the present results are of high practical relevance.

Interestingly, protein quality did not affect urinary Ox concentrations or renal Ox excretion. It was hypothesised that a higher amount of hydroxyproline and glycine, derived from collagen-rich greaves meal in the diets, would enhance endogenous Ox synthesis. Another study demonstrated that a diet with collagen tissue as the protein source led to higher urinary $\mathrm{Ox}$ excretion when compared with diets based on horse meat or soya protein isolate ${ }^{(2)}$. However, the authors also demonstrated that the diet with lower amounts of collagen tissue resulted in higher urinary Ox excretion than a diet with high amounts of collagen tissue. This observation might indicate that other dietary factors than specific amino acids derived from collagen tissue could be important for endogenous Ox synthesis. In particular, one factor could be a higher fat concentration in the diet. In this previous study ${ }^{(2)}$, the fat concentration in the diet with low amounts of collagen tissue was $24 \%$ on a DM basis, but in the diet with high amounts of collagen tissue $10 \%$, and it could be hypothesised that a higher dietary fat concentration enhanced endogenous Ox synthesis. Recent results ${ }^{(3)}$ support this assumption, as higher urinary Ox concentrations were measured when feeding a high-fat diet compared with a high-protein diet. Up to now, the potential mechanisms that lead to an increased renal $\mathrm{Ox}$ excretion by a high fat intake remain unclear. It is hypothesised that high dietary fat concentrations could contribute to a complexation between fatty acids and $\mathrm{Ca}$ in the intestine. This would reduce the available amounts of $\mathrm{Ca}$ for binding $\mathrm{Ox}$ and increase the intestinal $\mathrm{Ox}$ absorption and renal Ox excretion ${ }^{(38)}$. Schmiedl et al. ${ }^{(39)}$ suggest that hyperlipidaemia could increase hepatic Ox synthesis. The rats of this study showed hyperlipidaemia and elevated concentrations of lactate dehydrogenase $(\mathrm{LDH})$ in the blood when fed a high-fat diet. LDH can synthesise Ox from glycolate or other Ox precursors. Finally, the role of band 3 protein is discussed with regard to renal $\mathrm{Ox}$ excretion ${ }^{(38)}$. Band 3 protein is an anion transporter that catalyses the exchange of anions (for example, Ox) across a cell membrane. An activation (phosphorylation) of band 3 protein in erythrocytes in the intestine and kidneys can therefore increase intestinal $\mathrm{Ox}$ absorption and renal Ox excretion ${ }^{(38)}$. It has been demonstrated that arachidonic acid leads to a phosphorylation of band 3 protein in a dosedependent manner ${ }^{(40)}$.

It should be taken into consideration that the diets HQ $35 \%$, HQ $44 \%$ and HQ $57 \%$ showed some variations in fat concentrations $(115,124$ and $171 \mathrm{~g} / \mathrm{kg}$ DM, respectively). Thus, it cannot be excluded that the observed increase in renal $\mathrm{Ox}$ excretion associated with the high-protein diet could partly derive from the increase in dietary fat concentration. However, the diets HQ $57 \%$ and LQ $55 \%$ had comparable fat concentrations, independently of the amount of greaves meal. This aspect may be one reason for the observed similar urinary $\mathrm{Ox}$ concentrations and renal $\mathrm{Ox}$ excretion in these two groups. The present results highlight that a higher dietary amount of certain amino acids as potential precursors of endogenous Ox does not enhance endogenous Ox synthesis and may therefore be singularly no specific risk factor for the formation of $\mathrm{CaOx}$ uroliths in cats. In this context, it should not go unmentioned that the diets HQ $57 \%$ and LQ $55 \%$ varied in $\mathrm{Mg}$ concentrations (1.36 and $0.89 \mathrm{~g} / \mathrm{kg}$ $\mathrm{DM})$. High amounts of $\mathrm{Mg}$ can form a complex with $\mathrm{Ox}$ in the intestine, resulting in reduced intestinal absorption and renal excretion of $\mathrm{Ox}^{(41)}$. However, since no differences in urinary $\mathrm{Ox}$ concentrations or renal $\mathrm{Ox}$ excretion were observed between the two treatment groups, this effect seems to be negligible for the present study.

Urinary $\mathrm{Ca}$ concentrations and renal $\mathrm{Ca}$ excretion increased with increasing protein concentrations in the present experimental diets. This observation is consistent with findings in human subjects ${ }^{(17)}$. However, the main explanation for the increase in renal $\mathrm{Ca}$ excretion by a high protein intake is an acid load derived from the oxidation of sulfur-containing amino acids to sulfuric acid and the associated release of protons ${ }^{(18)}$. In the present study, urinary $\mathrm{pH}$ did not decrease with increasing concentrations of dietary protein, indicating that the enhanced renal $\mathrm{Ca}$ excretion was not mediated by an acid load. Nevertheless, although urinary sulfate concentrations were also unaffected by increasing dietary protein concentrations, daily renal sulfate excretion doubled from $30.6 \mathrm{mg} / \mathrm{kg}$ BW to $59.4 \mathrm{mg} / \mathrm{kg} \mathrm{BW}$, indicating an enhanced oxidation of sulfur-containing amino acids when feeding the high-protein diet. Another theory implies that a high-protein diet could enhance intestinal $\mathrm{Ca}$ absorption and consecutively also renal Ca excretion ${ }^{(21,22)}$. The present results did not demonstrate an increased apparent digestibility of $\mathrm{Ca}$, but a higher faecal $\mathrm{Ca}$ excretion when feeding the high-protein diet. Since renal $\mathrm{Ca}$ excretion also increased, a marked negative Ca balance was observed. It can therefore be hypothesised that the increase in urinary $\mathrm{Ca}$ concentrations and renal $\mathrm{Ca}$ excretion with increasing dietary protein concentrations did not derive from a higher intestinal $\mathrm{Ca}$ absorption, but potentially from a Ca mobilisation within the organism. A negative $\mathrm{Ca}$ balance associated with a high protein intake has also been observed in young $\mathrm{men}^{(42)}$, and a negative correlation between protein intake and bone mineral content as well as between protein intake and bone density has been identified in young women ${ }^{(43)}$. Future studies should therefore evaluate whether the demonstrated negative Ca balance associated with a highprotein diet also affects bone mass in cats.

With regard to the increase in urinary Ca concentrations and renal $\mathrm{Ca}$ excretion with increasing dietary protein concentrations, it should be finally mentioned that the crude fibre concentrations of the diets HQ $35 \%$, HQ $44 \%$ and HQ $57 \%$ were relatively low, but showed some variation $(11 \cdot 1,22 \cdot 8$ and $10.8 \mathrm{~g} / \mathrm{kg} \mathrm{DM}$, respectively). In our experience, the analysed crude fibre concentrations in cat food can vary 
considerably, which requires a careful interpretation of the results. Extremely high dietary fibre concentrations (11-14 $\%$ in $\mathrm{DM}$ ) have been reported to be associated with an increase in faecal DM excretion in cats, and faecal Ca excretion is positively correlated with faecal DM excretion ${ }^{(44)}$. These observations may indicate a reduction in intestinal Ca absorption by high dietary fibre concentrations, which has also been observed in rats when feeding diets with $2 \cdot 62-3 \cdot 25 \%$ crude fibre on a DM basis compared with a control diet with $0.77 \%$ crude fibre in $\mathrm{DM}^{(45)}$. As the present study demonstrated an increase in urinary $\mathrm{Ca}$ concentrations and renal $\mathrm{Ca}$ excretion, and no decrease was observed when feeding diet HQ $44 \%$, an effect on intestinal $\mathrm{Ca}$ absorption by varying crude fibre concentrations in the diets can be excluded.

Interestingly, renal Ca excretion was lower when feeding the diet with the higher amount of greaves meal (LQ $55 \%$ ). Up to now, the reason for this effect has remained unclear. Compared with diet LQ $55 \%$, diet HQ $57 \%$ contained less greaves meal and a mixture of poultry meal and soya protein. This mixture has ensured similar mineral and, with the exception of CP in the HQ groups, similar macronutrient concentrations compared with the other experimental diets. The apparent digestibility of CP tended to be higher in group HQ $57 \%$ compared with group LQ $55 \%$, which might have influenced the amino acid, mineral and acid base metabolism of the cats. It could be demonstrated that the urinary sulfate concentrations $(P \leq 0 \cdot 05)$, and the daily renal sulfate excretion $(P>0 \cdot 05)$ were higher when feeding diet HQ 57 $\%$ compared with diet LQ $55 \%$. However, since urinary $\mathrm{pH}$ was unaffected by protein quality in the diets, an acid load that enhanced renal $\mathrm{Ca}$ excretion when feeding diet HQ $57 \%$ could not be clearly detected. Thus, the potential impact of dietary protein quality on renal $\mathrm{Ca}$ excretion in cats cannot be conclusively clarified by the present study and needs further evaluation.

Urinary volume increased with higher protein concentrations in the diets. This finding is in accordance with previous studies in adult cats and kittens ${ }^{(7-9)}$. A higher dilution of the urine can generally be advantageous for the prevention of urinary crystals and stones ${ }^{(10)}$. However, since the higher dietary protein concentrations were also associated with an increased renal $\mathrm{Ca}$ and $\mathrm{Ox}$ excretion, the higher urinary volume seems to be of minor importance. Dietary protein quality did not affect the urinary volume of the cats. Urinary $\mathrm{pH}$ was relatively low among all experimental groups, reaching values between 6.34 and 6.66 . Since a urinary $\mathrm{pH}<6.29$ is considered to be a risk factor for the development of $\mathrm{CaOx}$ uroliths in cats ${ }^{(11,12)}$, the measured values were near to this critical range.

For the interpretation of the present results, limitations of the study design should finally not go unmentioned. In the present study, a four-period, four-treatment parallel cross-over design was used, which cannot eliminate carryover effects. However, the adaptation period was relatively long, and the cats were housed in a room with a constant light and temperature regimen; therefore constant conditions can reasonably be assumed for the present study.

In conclusion, the present data indicate that a high-protein diet cannot be considered as beneficial for the prevention of
$\mathrm{CaOx}$ uroliths in cats, as previously assumed. Although a higher urinary volume was also associated with a higher protein intake, the increased urinary $\mathrm{Ca}$ concentrations, renal $\mathrm{Ca}$ and $\mathrm{Ox}$ excretion and urinary RSS $\mathrm{CaOx}$ values are critical and potential risk factors for the formation of $\mathrm{CaOx}$ uroliths. In addition, the clinical relevance of the demonstrated negative Ca balance when feeding a high-protein diet should be further evaluated with regard to bone turnover. The impact of dietary protein quality on urine composition was generally low, with no effect on urinary $\mathrm{Ca}$ and $\mathrm{Ox}$ concentrations, RSS $\mathrm{CaOx}$ or renal Ox excretion. However, the observed lower renal $\mathrm{Ca}$ excretion in cats that received a diet with a higher amount of collagen-rich greaves meal needs further investigation.

\section{Acknowledgements}

There was no specific funding provided for the present study.

The contribution of the authors was as follows: H. B., T. B. and J. Z. designed and organised the study; H. B. performed the analysis of urine and faeces; N. P. wrote the manuscript; N. P., H. B. and K. N. carried out the data analysis; J. Z. revised the manuscript.

There are no conflicts of interest.

\section{References}

1. Nguyen QV, Kalin A, Drouve U, et al. (2001) Sensitivity to meat protein intake and hyperoxaluria in idiopathic calcium stone formers. Kidney Int 59, 2273-2281.

2. Zentek J \& Schulz A (2004) Urinary composition of cats is affected by the source of dietary protein. J Nutr 134, 2162S-2165S.

3. Dijcker JC, Hagen-Plantinga EA \& Hendriks WH (2012) Changes in dietary macronutrient profile do not appear to affect endogenous urinary oxalate excretion in healthy adult cats. Vet J 194, 235-239.

4. Masai M, Ito H \& Kotake T (1995) Effect of dietary intake on urinary oxalate excretion in calcium oxalate stone formers. BrJ Urol 76, 692-696.

5. Naya Y, Ito H, Masai M, et al. (2000) Effect of dietary intake on urinary oxalate excretion in calcium oxalate stone formers in their forties. Eur Urol 37, 140-144.

6. Dijcker JC, Plantinga EA, van Baal J, et al. (2011) Influence of nutrition on feline calcium oxalate urolithiasis with emphasis on endogenous oxalate synthesis. Nutr Res Rev 24, 96-110.

7. Hashimoto M, Funaba M, Abe M, et al. (1995) Dietary protein levels affect water intake and urinary excretion of magnesium and phosphorus in laboratory cats. Exp Anim 44, 29-35.

8. Funaba M, Hashimoto M, Yamanaka C, et al. (1996) Effects of a high-protein diet on mineral metabolism and struvite activity product in clinically normal cats. Am J Vet Res 57, 1726-1732.

9. Hashimoto M, Funaba M, Abe M, et al. (1996) Effect of chronic high protein intake on magnesium, calcium, and phosphorus balance in growing cats. Exp Anim 45, 63-70.

10. Kerr KR (2013) Companion Animals Symposium: dietary management of feline lower urinary tract symptoms. J Anim Sci 91, 2965-2975.

11. Kirk CA, Ling GV, Franti CE, et al. (1995) Evaluation of factors associated with development of calcium oxalate urolithiasis in cats. J Am Vet Med Assoc 207, 1429-1434.

12. Osborne CA, Lulich JP, Thumchai R, et al. (1995) Etiopathogenesis and therapy of feline calcium oxalate urolithiasis. In Proceedings of the 13th Annual ACVIM Forum, Orlando, FL, pp. 487-489. Lakewoood, CO: American College of Veterinary Internal Medicine (ACVIM).

13. Funaba M, Yamate T, Hashida Y, et al. (2003) Effects of a highprotein diet versus dietary supplementation with ammonium 
chloride on struvite crystal formation in urine of clinically normal cats. Am J Vet Res 64, 1059-1064.

14. Funaba M, Oka Y, Kobayashi S, et al. (2005) Evaluation of meat meal, chicken meal, and corn gluten meal as dietary sources of protein in dry cat food. Can J Vet Res 69, 299-304.

15. Negri AL, Spivacow FR \& Del Valle EE (2013) Diet in the treatment of renal lithiasis. Pathophysiological basis. Medicina (B Aires) 73, 267-271.

16. Zemel MB, Schuette SA, Hegsted M, et al. (1981) Role of the sulfur-containing amino acids in protein-induced hypercalciuria in men. J Nutr 111, 545-552.

17. Bihuniak JD, Simpson CA, Sullivan RR, et al. (2013) Dietary protein-induced increases in urinary calcium are accompanied by similar increases in urinary nitrogen and urinary urea: a controlled clinical trial. J Acad Nutr Diet 113, 447-451.

18. Sabry ZI, Shadarevian SB, Cowan JW, et al. (1965) Relationship of dietary intake of sulphur amino-acids to urinary excretion of inorganic sulphate in man. Nature 206, 931-933.

19. Ceglia L, Harris SS, Abrams SA, et al. (2009) Potassium bicarbonate attenuates the urinary nitrogen excretion that accompanies an increase in dietary protein and may promote calcium absorption. J Clin Endocrinol Metab 94, 645-653.

20. Maalouf NM, Moe OW, Adams-Huet B, et al. (2011) Hypercalciuria associated with high dietary protein intake is not due to acid load. J Clin Endocrinol Metab 96, 3733-3740.

21. Kerstetter JE, O'Brien KO, Caseria DM, et al. (2005) The impact of dietary protein on calcium absorption and kinetic measures of bone turnover in women. J Clin Endocrinol Metab 90, 26-31.

22. Hunt JR, Johnson LK \& Fariba Roughead ZK (2009) Dietary protein and calcium interact to influence calcium retention: a controlled feeding study. Am J Clin Nutr 89, 1357-1365.

23. Piccoli A, Calò L, Modena F, et al. (1991) Prostaglandins and renal response to protein loading in normal and glomerulonephritic kidneys: effect of indomethacin and dipyridamole. Curr Ther Res Clin Exp 49, 596-609

24. Calò L, Cantaro S, Marchini F, et al. (1990) Is hydrochlorothiazideinduced hypocalciuria due to inhibition of prostaglandin $\mathrm{E}_{2}$ synthesis? Clin Sci 78, 321-325.

25. Baggio B (2004) Protein diet and hypercalciuria. Kidney Int 65, 1970; author reply 1970.

26. Laser Reutersward A, Asp NG \& Bjork I (1985) Protein digestibility of pigskin and bovine tendon in rats. J Food Technol 20, 745-752.

27. Knight J, Jiang J, Assimos DG, et al. (2006) Hydroxyproline ingestion and urinary oxalate and glycolate excretion. Kidney Int 70, 1929_ 1934.

28. Knight J, Easter LH, Neiberg R, et al. (2009) Increased protein intake on controlled oxalate diets does not increase urinary oxalate excretion. Urol Res 37, 63-68.

29. National Research Council (2006) Nutrient Requirements of Dogs and Cats. Washington, DC: The National Academies Press.

30. Paßlack N, Brenten T, Neumann K, et al. (2014) Investigations on the effects of potassium chloride and potassium bicarbonate in the diet on the urinary $\mathrm{pH}$ and mineral excretion of adult cats. BrJ Nutr 111, 785-797.
31. Naumann C \& Bassler C (2004) Die chemische Untersuchung von Futtermitteln 3. Aufl., 5. Ergänzungshieferung (Chemical Feed Analyses, Vol. 3). Darmstadt: VDLUFA-Verlag.

32. Passlack N \& Zentek J (2013) Urinary calcium and oxalate excretion in healthy adult cats are not affected by increasing dietary calcium levels. PLOS ONE 8, e70530.

33. Gericke S \& Kurmies B (1952) Colorimetrische Bestimmung der Phosphorsäure mit Vanadat-Molybdat (Colorimetric determination of phosphoric acid with vanadate molybdate). Fres Zeitsch Anal Chem $137,15-22$.

34. Robertson WG, Jones JS, Heaton MA, et al. (2002) Predicting the crystallization potential of urine from cats and dogs with respect to calcium oxalate and magnesium ammonium phosphate (struvite). J Nutr 132, 1637S-1641S.

35. Lekcharoensuk C, Osborne CA, Lulich JP, et al. (2001) Association between dietary factors and calcium oxalate and magnesium ammonium phosphate urolithiasis in cats. J Am Vet Med Assoc 219, 12281237.

36. Siener R, Honow R, Voss S, et al. (2006) Oxalate content of cereals and cereal products. J Agric Food Chem 54, 3008-3011.

37. Massey LK (2007) Food oxalate: factors affecting measurement, biological variation, and bioavailability. J Am Diet Assoc 107, 1191-1194.

38. Naya Y, Ito H, Masai M, et al. (2002) Association of dietary fatty acids with urinary oxalate excretion in calcium oxalate stoneformers in their fourth decade. BJU Int 89, 842-846.

39. Schmiedl A, Schwille PO, Bonucci E, et al. (2000) Nephrocalcinosis and hyperlipidemia in rats fed a cholesterol- and fat-rich diet: association with hyperoxaluria, altered kidney and bone minerals, and renal tissue phospholipidcalcium interaction. Urol Res 28, 404-415.

40. Baggio B, Priante G, Brunati AM, et al. (1999) Specific modulatory effect of arachidonic acid on human red blood cell oxalate transport: clinical implications in calcium oxalate nephrolithiasis. $J$ Am Soc Nephrol 10, S381-S384.

41. Morozumi M, Hossain RZ, Yamakawa K, et al. (2006) Gastrointestinal oxalic acid absorption in calcium-treated rats. Urol Res 34, 168-172.

42. Hegsted M, Schuette SA, Zemel MB, et al. (1981) Urinary calcium and calcium balance in young men as affected by level of protein and phosphorus intake. J Nutr 111, 553-562.

43. Metz JA, Anderson JJ \& Gallagher PN Jr (1993) Intakes of calcium, phosphorus, and protein, and physical-activity level are related to radial bone mass in young adult women. Am J Clin Nutr 58, 537-542.

44. Prola L, Dobenecker B, Mussa PP, et al. (2010) Influence of cellulose fibre length on faecal quality, mineral excretion and nutrient digestibility in cat. J Anim Physiol Anim Nutr (Berl) 94, 362367.

45. Gralak MA, Leontowicz M, Morawiec M, et al. (1996) Comparison of the influence of dietary fibre sources with different proportions of soluble and insoluble fibre on $\mathrm{Ca}, \mathrm{Mg}, \mathrm{Fe}, \mathrm{Zn}, \mathrm{Mn}$ and $\mathrm{Cu}$ apparent absorption in rats. Arch Tierernabr 49, 293-299. 